\title{
Desain Sistem Pelacakan Muatan Kapal Pelra
}

\author{
Wira Yudha Pambudi, Setyo Nugroho dan Eka Wahyu Ardhi \\ Departemen Teknik Transportasi Laut, Institut Teknologi Sepuluh Nopember (ITS) \\ e-mail: snugroho@seatrans.its.ac.id
}

\begin{abstract}
Abstrak-Dari segi pelayanan bisnisnya Pelayaran Rakyat masih tradisional dikarenakan pertukaran informasi yang sangat minim dan hanya bisa diakses dengan komunikasi secara langsung dengan pihak pelayaran, kini banyak pelanggan yang meninggalkannya karena kurang praktis dan kepercayaan terhadap angkutan barangnya. Pihak pengguna hanya bisa menunggu kabar melalui tatap muka dan sambungan telepon jadi tidak bisa mengetahui titik pasti keberadaan barangnya. Dengan adanya kendala tersebut maka dibutuhkan sebuah alat dan wadah sebagai sumber pertukaran informasi yang baik. Pada kenyataanya saat ini para pemilik barang yang hendak mengirimkan barangnya harus mengirimkan dengan jumlah berlebih dikarenakan pasti ada kerusakan ataupun kehilangan muatan dikarenakan proses perpindahan barang saat ini. Kemampuan untuk tracking dan tracing sangat penting bagi upaya mempertemukan pasokan dan permintaan suatu komoditi. Tracking and Tracing system yang handal, akan diperoleh manfaat atau keuntungan, antara lain: 1. prosedur identifikasi dan penyusuran serta penelusuran produk/komoditi dari tahap produksi, distribusi, dan instalasi; 2 . ketersediaan informasi tentang bagian-bagian yang terdapat dalam sebuah produk/komoditi, seperti spesifikasi, status produk/komoditi, jumlah, dan lain-lain; Selain itu menggunakan alat pelacak muatan berupa barcode scanner dan website yang menghasilkan nilai Benefit Cost Ratio (BCR) yaitu 1,55.
\end{abstract}

Kata Kunci-Angkutan Pelra, Track and Tracing Muatan, Analisis Biaya-Manfaat.

\section{PENDAHULUAN}

$\mathrm{P}$ ELAYARAN-rakyat adalah salah satu angkutan laut yang ada di Indonesia, sebagaimana tercantum dalam Undang-undang Nomor 17 Tahun 2008 tentang Pelayaran. Jenis pelayaran ini adalah pelayaran tradisional yang merupakan warisan budaya bangsa Indonesia. Oleh sebab itu, Pemerintah berketetapan untuk tetap mempertahankan jenis pelayaran ini. Karakteristik utamanya adalah kapal yang terbuat dari kayu, sebagian masih memanfaatkan layar sebagai tenaga penggerak, dan lebih banyak mengangkut barang atau hewan. Melemahnya industri Pelayaran Rakyat sejak tahun 2016 belakangan memperlihatkan ada sesuatu yang tidak berjalan sebagaimana mestinya, bisa dari sisi internal pelayaran-rakyat atau bisa juga dari sisi eksternal yang dapat berasal dari kebijakan pemerintah maupun faktor lainnya.

Dari segi pelayanan bisnisnya Pelayaran Rakyat masih tradisional dikarenakan pertukaran informasi yang sangat minim dan hanya bisa diakses dengan komunikasi secara langsung dengan pihak pelayaran, kini banyak pelanggan yang meninggalkannya karena kurang praktis dan kepercayaan terhadap angkutan barangnya. Pihak pengguna hanya bisa menunggu kabar melalui tatap muka dan sambungan telepon jadi tidak bisa mengetahui titik pastikeberadaanbarangnya. Dengan adanya kendala tersebut maka dibutuhkan sebuah alat dan wadah sebagai sumber pertukaran informasi yang baik. Pada kenyataanya saat ini para pemilik barang yang hendak mengirimkan barangnya harus mengirimkan dengan jumlah berlebih dikarenakan pasti

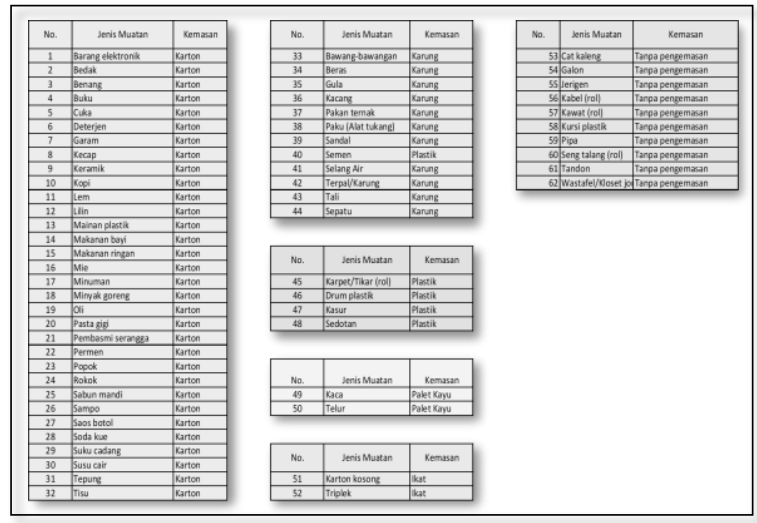

Gambar 1. Kategori Muatan Pelra.

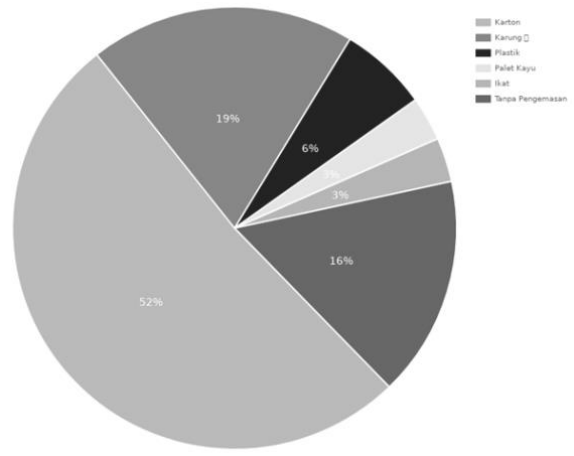

Gambar 2. Grafik Presentase Muatan Pelra.

ada kerusakan ataupun kehilangan muatan dikarenakan proses perpindahan barang saat ini.

Dalam dunia industri, transportasi merupakan salah satu aktivitas utama dalam sistemlogistik dan memiliki peranan yang penting dalam perusahaan. Pengiriman barang memiliki suatu misi yaitu mengirimkan barang yang benar pada tempat dan waktu yang tepat.Agar misi tersebut dapat tercapai maka diperlukan suatu sistem yang mampu untuk:

1. Menjamin barang yang dikirim memiliki jumlah yang sesuai dengan permintaan dari konsumen

2. Memastikan waktu pengiriman secara tepat sesuai dengan jarak tempuh pengiriman

3. Menjaga keamanan dan kualitas barang pada saat pengiriman.

Kemampuan untuk tracking dan tracing sangat penting bagi upaya mempertemukan pasokan dan permintaan suatu komoditi, menyatakan dengan tersedianya tracking and tracing system yang handal, akan diperoleh manfaat atau keuntungan, antara lain:

1. Prosedur identifikasi dan penyusuran serta penelusuran produk/komoditi dari tahap produksi, distribusi, dan instalasi;

2. Ketersediaan informasi tentang bagian-bagian yang terdapat dalam sebuah produk/komoditi, seperti spesifikasi, status produk/komoditi, jumlah, dan lainlain; 


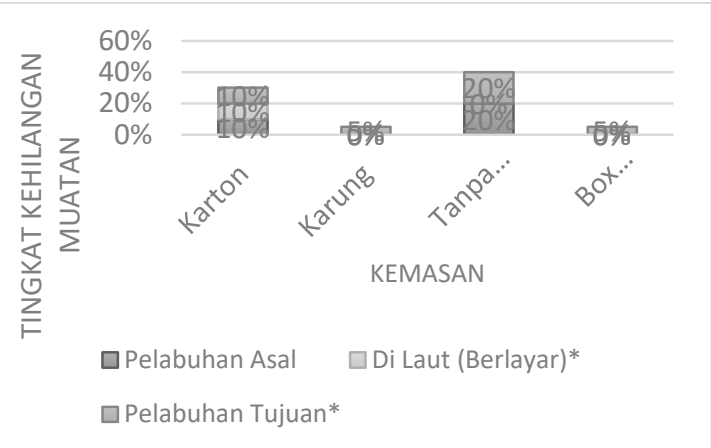

Gambar 3. Grafik Tingkat Kehilangan Muatan.

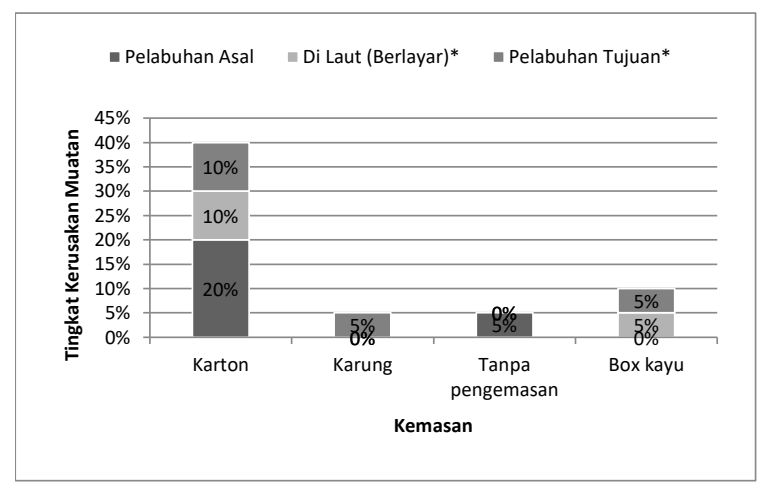

Gambar 4. Grafik Tingkat Kerusakan Muatan.

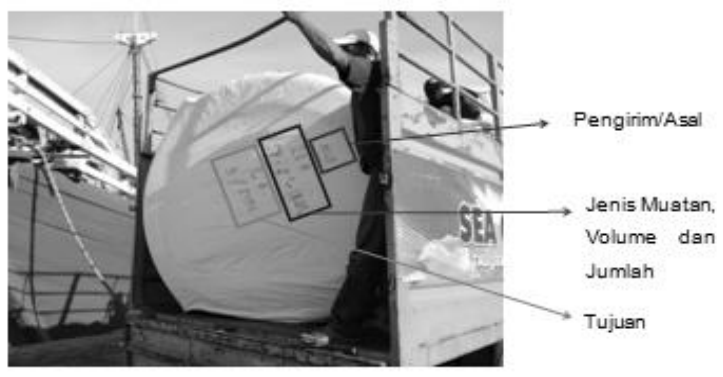

Gambar 5. Pelabelan Muatan Pelra Saat Ini.

3. Ketersediaan informasi tentang isi yang tepat tentang produk/komoditi tersebut;

4. Membantu ke arah pencapaian process control. Selain itu, fungsi tracking pada suatu komoditi akan membantu konsumen maupun produsen untuk mengetahui para pelaku bisnis dalam rantai pasok tersebut, termasuk di dalamnya bagaimana cara para pelaku dalam menangani produk/komoditi.

Keberadaan tracking and tracing system pada akhirnya akan menjamin kepastian kuantitas dan kualitas suatu produk atau komoditi secara tepat [1]. Dalam proses distribusi komoditi, kebutuhan tracking and tracing system perlu didenifisikan secara jelas. Saat ini, dalam dunia perdagangan, dikenal dua model mekanisme tracking and tracing system, yaitu:

a. terpusat (centralized);

b. terdesentralisi (decentralized)

\section{METODE PENELITIAN}

\section{A. Identifikasi Proses Bisnis}

Tahap ini dilakukan untuk memahami kondisi terkini dari pelabuhan rakyat (Kalimas). Proses bisnis dirasa perlu untuk ditelusuri, karena semua pihak di pelra memiliki keterkaitan dalam pertukaran informasi dan data. Dengan melakukan

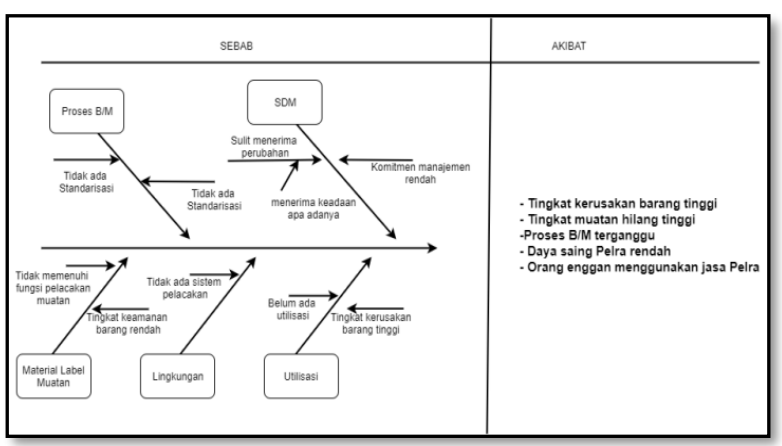

Gambar 6. Diagram Sebab Akibat.

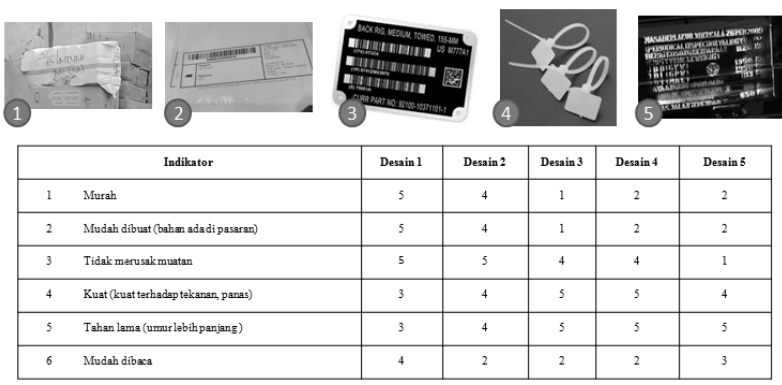

Gambar 7. Jenis-Jenis Material Label Muatan.

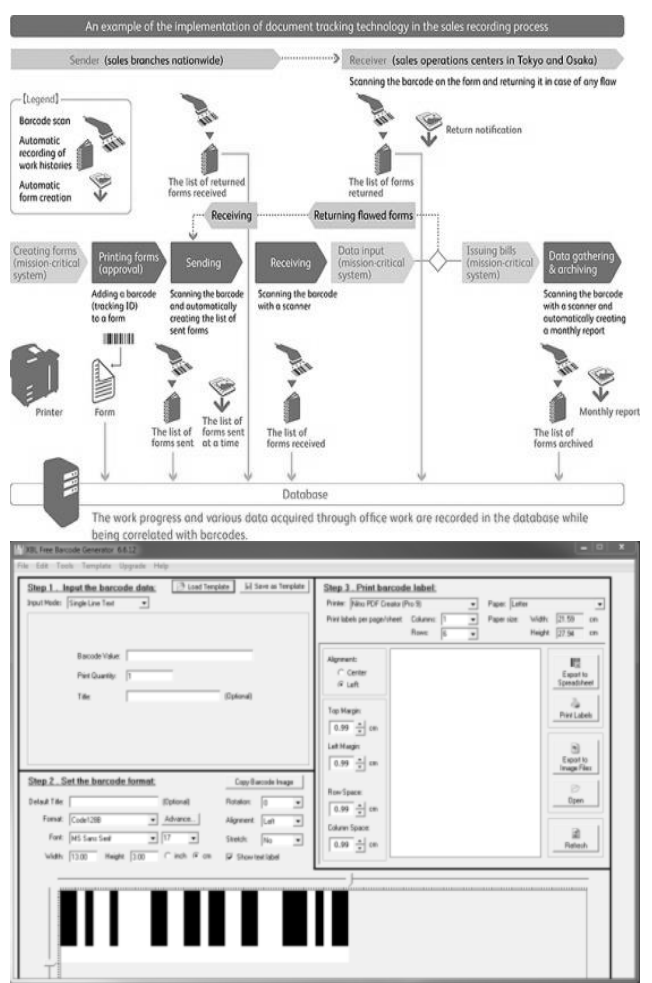

Gambar 8. Tampilan Aplikasi Barcodes Generator.

identifikasi proses bisnis, maka bisa didapatkan struktur dari arsitektur Organisasi dan ITS yang tepat untuk pelra.

\section{B. Studi Literatur}

Materi yang menjadi rujukan pada penelitian tugas akhir mengenai indikator Konsep ITS (Intelligent Transport System), Arsitektur ITS, dan metode untuk mengetahui kelayakan model arsitektur ITS menggunakan cost benefit analysis.

\section{Wawancara}

Pengumpulan data dengan berkomunikasi secara langsung dari sumber yang bersangkutan yang berada dalam lingkungan pelra Kalimas. 
Enter data for barcode:

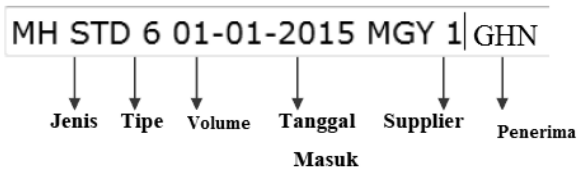

Gambar 9. Spesifikasi Barcode.

Result:

Code 128 Barcode for input data 'MH STD 6 01-01-2015 MGY 1'

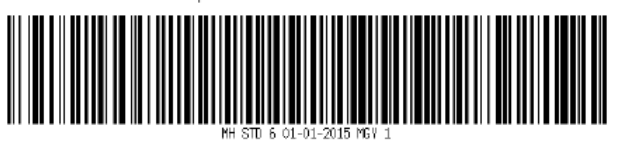

Gambar 10. Hasil Barcodes Menggunakan Generator.

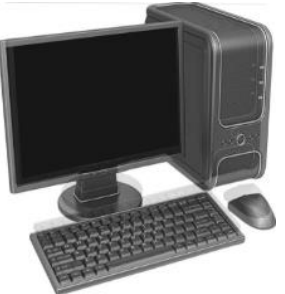

Gambar 11. Komputer Pentium IV.

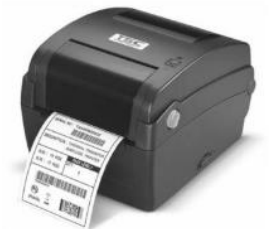

Gambar 12. Barcodes Printer

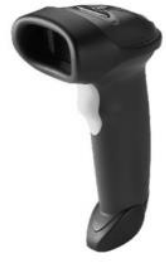

Gambar 13. Barcodes Scanner

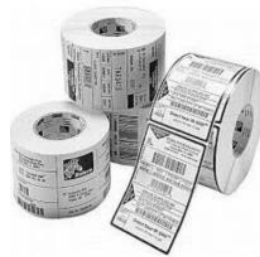

Gambar 14. Barcodes Sticker Label.

\section{Observasi}

Pengamatan dan peninjauan langsung proses penanganan muatan di dermaga kalimas.

\section{E. Validasi data}

Bertujuan untuk menguji ketepatan antara data yang terkumpul dengan data yang sesungguhnya terjadi pada obyek yang diteliti.

\section{F. Analisis Kebutuhan Pengguna}

Dalam penelitian ini dilakukan analisis dari permasalahan yang terjadi di lapangan untuk mendapatkan kasus yang benar - benar kongkrit dan nyata. Dari analisis Kebutuhan pengguna maka akan didapatkan bayangan dan asumsi awal dari permasalahan sehingga penulis dapat merancang desain arsitektur ITS dengan tujuan menyelesaikan permasalahan yang terjadi di Pelra dengan sudut pandang dari sisi pemasaran dan kebutuhan pengguna aplikasi atau website seluler.

\section{G. Pembangunan Kerangka (Framework) ITS}

Pada proses ini dilakukan pembangunan kerangka atau framework ITS berdasarkan data-data dan dasar teori yang telah diperoleh pada tahap-tahap sebelumnya. Di dalam kerangka ITS ini terdapat proses bisnis yang ditampilkan pada setiap sudut pandang setiap pemangku kepentingan. Selain itu pada proses ini juga merencanakan proses pertukaran data elektronik (Data Interchange) dari masingmasing pelaku bisnis. Kerangka ITS dibangun berdasarkan arsitektur sistem dan arsitektur komunikasi. Pembangunan kerangka berdasarkan ada setiap bagian yang lebih kecil dari

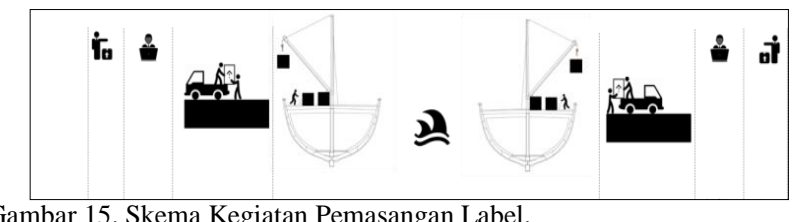

Gambar 15. Skema Kegiatan Pemasangan Label.

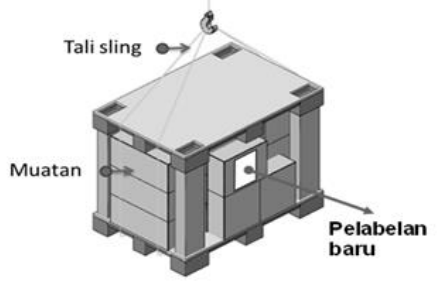

Gambar 16. Proses Penempelan Label Pada Kemasan.

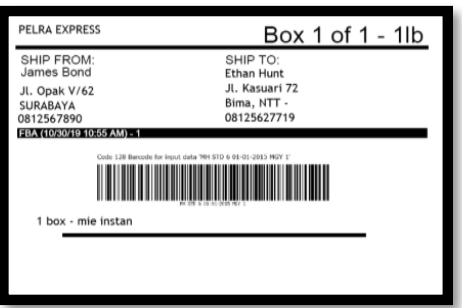

Gambar 17. Label Muatan Baru.

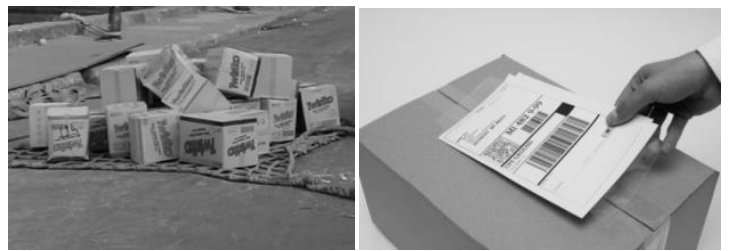

Gambar 18. Label Muatan Pada Kardus.
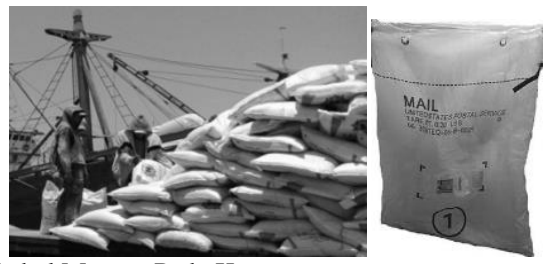

Gambar 19. Label Muatan Pada Karung.

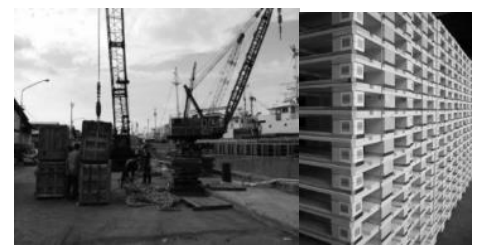

Gambar 20. Label Muatan Pada Palet Kayu.

arsitektur organisasi sebuah proses perpindahan barang, informasi, dan uang.

\section{H. Analisis Biaya-Manfaat (CBA Framework)}

Setelah membangun kerangka ITS maka dapat dilakukan analisis biaya-manfaat melalui identifikasi biaya-biaya yang ditimbulkan oleh sistem ini serta perhitungan manfaatmanfaat yang ditimbulkan baik manfaat secara tangible maupun intangible. Kemudian melakukan konversi terhadap nilai uang dari biaya dan manfaaat tersebut agar dapat dijadikan rasio perbandingan.

\section{Pembuatan Mockup}

Mockup menjadi salah satu output dari penelitian ini, berfungsi sebagai sebuah media visual atau preview dari 


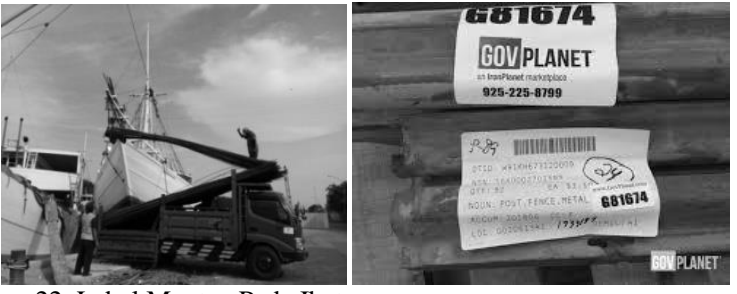

Gambar 22. Label Muatan Pada Ikatan.
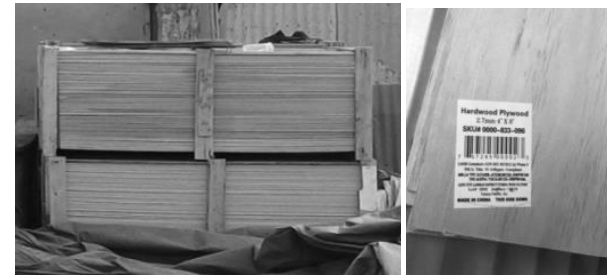

Gambar 23. Label Muatan Pada Triplek.

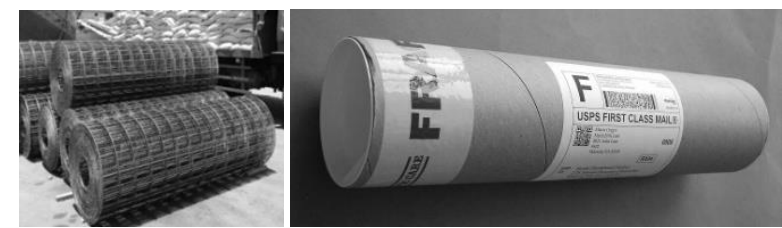

Gambar 24. Label Muatan Pada Gulungan.

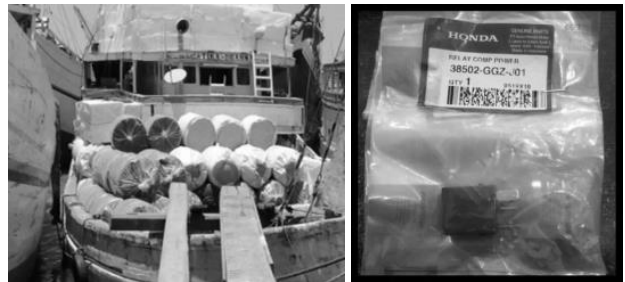

Gambar 25. Label Muatan Pada Plastik.

sebuah konsep desain. Mockup dapat memberikan gambaran nyata dari sebuah konsep desain bagaimana konsep itu akan terlihat nantinya jika sudah diaplikasikan menjadi aplikasi mobile apps ataupun website penunjang.

\section{ANALISIS DAN PEMBAHASAN}

\section{A. Jenis Muatan Pelra}

Muatan yang diangkut oleh armada kapal pelayaran rakyat adalah general cargo biasanya terdiri dari berbagai jenis kebutuhan sehari-hari, meliputi dari semen, pupuk, beras, dan lain sebagainya. Struktur kemasan fisik barang atau muatan pelayaran rakyat sangat beragam, diantaranya berbentuk karungan, karton, dan lain sebagainya. Gambar 1 dan Gambar 2 merupakan penggolongan jenis barang sesuai kemasan pengangkutannya. Dalam muatan pelra yang paling dominan adalah muatan karton sebesar 52\% dari total semua jenis muatan yang dikemas dan muatan karung terbanyak kedua sebanyak 19\% serta muatan paling sedikit adalah muatan dengan ikat dan palet kayu sebesar 3\% dari total semua jenis muatan.

\section{B. Penangan Muatan Pelra}

Dengan penanganan muatan yang berbasis tenaga manusia cenderung sulit untuk melakukan kontrol terhadap muatan, karena kita sulit memperkirakan waktu perpindahan barangnya dalam hitungan menit. Tidak jarang barang hilang dalam proses ini karena tidak adanya pencatatan yang baik dan di Pelra kerusakan barang cukup tinggi dan fakta dalam

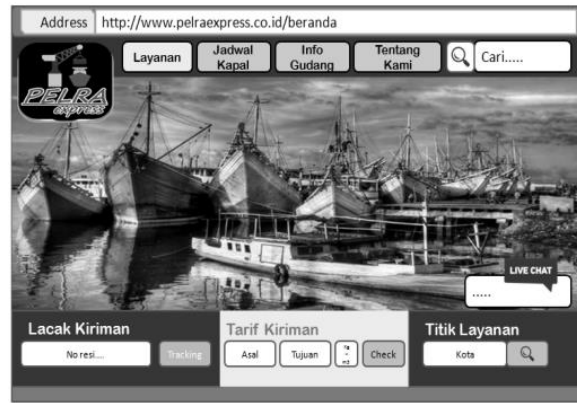

Gambar 26. Desain Mock Up Halaman Utama Website.

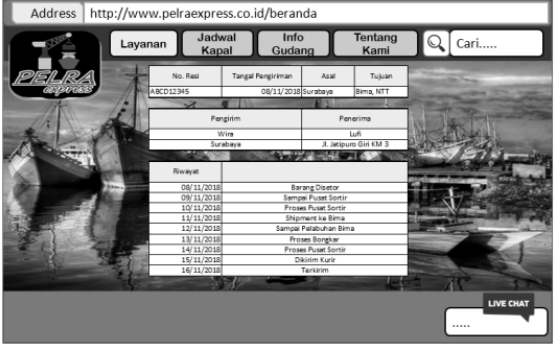

Gambar 27. Desain Mock Up Halaman Pelacakan.

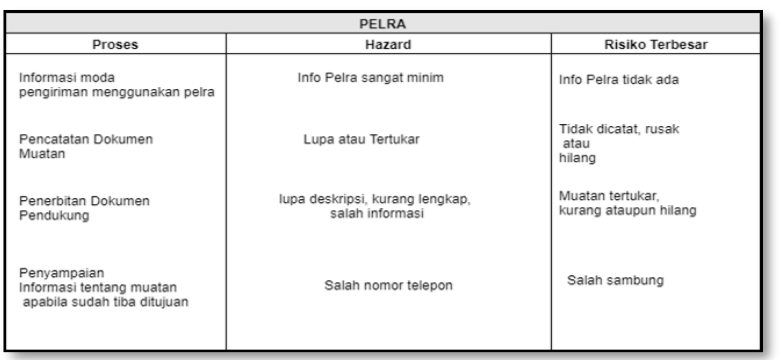

Gambar 28. Risiko Pelra.

lapangan, kerusakan luar seperti kemasan tidak ada ganti rugi dan kedua belah pihak saling memaklumi. (Gambar 3 dan 4)

\section{Pelabelan Muatan Pelra Saat Ini}

Di Pelra muatannya beragam tapi biasanya satu jenis muatan ditujukan kepada satu orang yang sama, jadi apabila ada salah satu label yang rusak kitamasih tau mau kemana barang itu dikirim. Tapi kita masih tetap harus laporan ke agen total muatan yang diangkut ada berapa. Jadi secara tidak langsung label rusak sedikit menjadi penghambat TKBM untuk mengangkut muatan ke kapal. Untuk saat ini proses pelabelan hanya sebatas coret-coretan menggunakan spidol pada kemasan muatan, meskipun saat ini tiap perusahaan pelayaran punya kode label sendiri - sendiri tapi masih jauh dari standar untuk mengatasi barang tanpa pengemesan yang sering hilang dan sering tertukar di rute tujuan yang lain. (Gambar 5)

\section{Identifikasi Faktor Penyebab Permasalahan}

Dalam memudah kan proses identifikasi masalah, makadigunakan diagram sebab akibat (fishbone framework), dimana diagram sebab akibat ini memberikan ringkasan dari lima sudut pandang berbeda yang selanjutnya digunakan untuk pengembanga nsistem pelacakan di pelayaran rakyat. Kerangka ini sangat membantu untuk memahami kondis iterkini mengenai alat untuk melacak yang digunakan di pelayaran rakyat serta untuk memberikan strategi atau ide pelacakan untuk meningkatkan efisiensi pelacakan selanjutnya. (Gambar 6) 


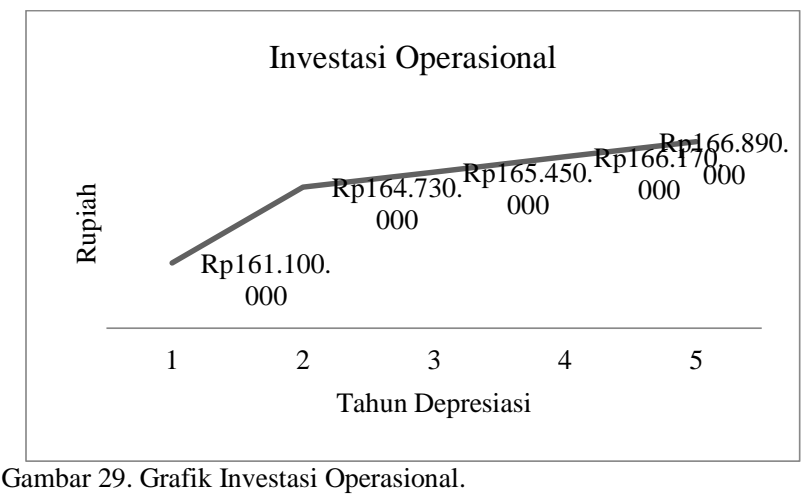

\section{E. Kriteria Pelabelan Yang Diinginkan Pelra}

Berdasarkan hasil survei yang telah dilakukan, terdapat 6 (enam) poin penting yang disampaikan oleh stakeholder $r$ terkait di pelra (DPC Pelra Surabaya, pemilikbarang, TKBM, ABK, dll), diantaranya:

\section{1) Murah}

Prinsip utama dari pelayanan jasa pelayaran rakyat adalah dengan menekan biaya seminimal mungkin. Oleh karena itu, pointer penting pertama yang ditekankand alam penelitian ini adalah pengeluaran biaya semurah mungkin. Untuk mengukur seberapa murah kemasan yang didesain oleh penulis dalam penelitianini, maka dilakukan perhitungan mengenai tariff atau ongkos muata baru yang dikenakan akibat penggunaan kemasan.

\section{2) Mudah dibuat (bahan ada di pasaran);}

Sebagai jasa angkutan laut tradisional dengan skala yang lebih kecil dari pada jasa angkutan laut niaga, kemasan yang dibuat diharapkan dapat diproduksi missal sendiri.

3) Tidak merusak muatan;

Tentunya tujuan dari penggunaan kemasan tersier di pelra yaitu untuk mengurangi tingkat kerusakan muatan sehingga diharapkan pemilik muatan menjadi tertarik untuk menggunakan jasa angkutan pelayaranr akyat.

\section{4) Kuat;}

Kuat di sini diartikan kemasan yang didesain mampu untuk menahan beban muatan yang beragam.

5) Tahan lama;

Tentunya kemasan yang didesain memiliki umur ekonomis sesuai dengan bahan yang digunakan.

6) Mempermudah proses B/M, baik dengan Derek maupun TKBM;

Seperti diketahui bahwa penanganan muatan di pelayaran rakyat masih sederhana sehingga diharapkan dengan kemasan yang didesain mampu untuk mengurangi waktu B/M dan memiliki nilai ergonomic untuk TKBM. (Gambar 7)

\section{F. Skema Pelacakan Dengan Label Terpilih}

Barcode adalah alat elektronik yang menunjukkan label yang digunakan untuk mengidentifikasi identitas dari suatu material. Dengan menerapkan system barcode, proses pencatatan dan pemrosesan data dapat berjalan dengan cepat, tepat dan akurat sehingga mampu menyediakan informasi secara optimal yang dapat digunakan untuk keperluan Pelra. Simbol barcode dapat dirancang menggunakan aplikasi yang telah banyak beredar seperti tipe Codabar, Cod 11, Code 39, Code 93, Code 128, EAN, UPC, dan sebagainya. Pada kasus ini digunakan barcode Code 128 untuk menyelesaikan masalah yang ada. Adapun software yang digunakan adalah Barcode Generator ditunjukkan pada Gambar 7 dan 8:

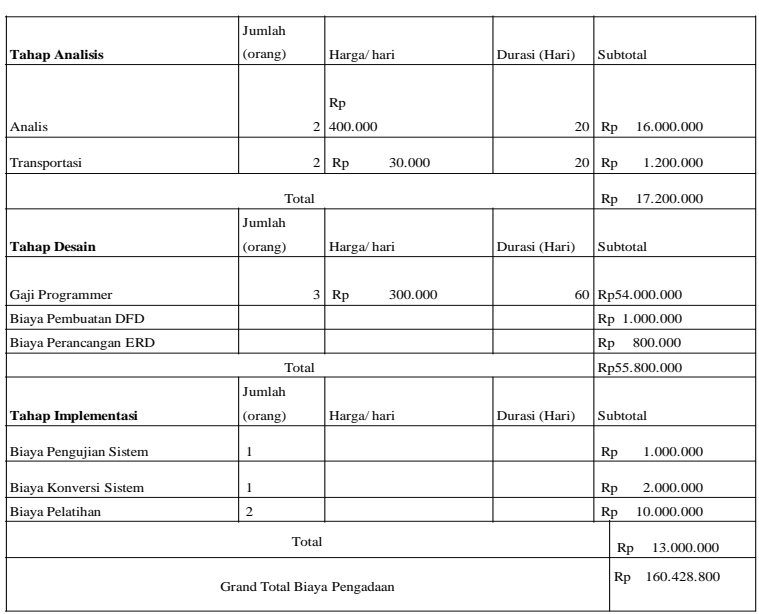

Gambar 30. Total Biaya Pengadaan.

\section{G. Analisis Perancangan Barcodes}

Dalam perancangan system barcode ini, data material yang masuk akan diwakili dengan jenis muatan, tipe muatan, volume muatan, tanggal masuk muatan, nama supplier dan penerima.

Spesifikasi Barcode ditunjuukan pada Gambar 9 dan 10.

Stiker barcodes yang dirancang harus mampu mengakomodasi informasi-informasi yang dibutuhkan dalam proses penginputan material yang masuk maupun yang keluar serta mampu menggantikan proses manual yang sudah berjalan sebelumnya. Berdasarkan proses aliran muatan yang terdapat di Pelra, stiker barcode yang dirancang adalah stiker barcode yang ditempelkan pada material muatan. Stiker barcode yang dirancang untuk ditempelkan pada muatan akan menggantikan fungsi kertas ataupun coretan spidol identitas yang biasa ditempelkan pada muatan tersebut. Oleh karena itu, dibutuhkan informasi yang lengkap pada stiker barcode ini.

\section{H. Analisis Kebutuhan Perangkat Keras Penunjang Sistem \\ 1) Komputer}

Komputer (Gambar 11) yang digunakan sebagai komputer barcode memiliki spesifikasi minimal Pentium IV. Komputer ini akan terhubung dengan inputan data yang dilakukan oleh barcode scanner. Diperkirakan jumlah computer yang akan dipakai untuk keperluan penginputan data dengan system barcode berjumlah 2 buah.

\section{2) Barcodes Printer}

Barcode printer (Gambar 12) merupakan printer yang digunakan untuk mencetak stiker barcode sesuai dengan data yang telah dibuat. Printer ini harus disesuaikan dengan ukuran stiker yang akan digunakan.

\section{3) Barcodes Scanner}

Barcode scanner (Gambar 13) digunakan sebagai alat pemindaian barcode untuk input data transaksi material yang masuk dan keluar di tiap-tiap area warehouse. Barcode scanner sendiri banyak dijual dengan spesifikasi yang beragam sesuai dengan kebutuhan pemakai. Warehouse sebaiknya menggunakan barcode scanner jenis $R F$ Cordless Wireless Barcode Scanner. Barcode jenis ini lebih mudah dan fleksibel digunakan di area penerimaan dan penyimpanan material yang rentan mengalami kerusakan dan mempersulit operator ketika melakukan pemindaian. Prinsip kerja wireless 
Perbandingan Waktu Arsitektur Komunikasi

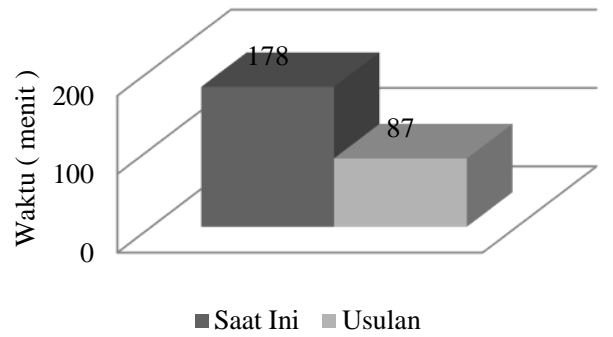

Gambar 31. Grafik Analisis Waktı

scanner mirip dengan bluethooth sebagai sarana radio frequency dan menerima/mengirim sinyal ke computer dengan jarak jangkauan kerja sampai sejauh $100 \mathrm{~m}$.

4) Barcodes Sticker Label

Barcode label (Gambar 14) merupakan kertas stiker yang digunakan untuk mencetak label barcode dan informasi lain yang telah dirancang di dalam stiker barcode yang kemudian akan ditempelkan pada setiap kemasan material. Barcode label yang digunakan berjenis ceramic barcode label. Barcode ini dirancang agar tahan terhadap temperature yang tinggi. Sebab tidak dipungkiri saat proses penyimpanan material di warehouse material mengalami perubahanperubahan suhu yang signifikan.

\section{Proses Pelackan Muatan}

Dalam proses pelacakan muatan (Gambar 15) dengan label baru saat ini dimulai dari pengirim mengantar muatannya terlebih dahulu ke agen atau langsung bisa ke dermaga Kalimas, lalu pihak agen pelra mencatat tiap muatannya dalam database komputer lalu menerbitkan barcode muatan, setelah tercetak jenis barcode untuk tiap jenis muatan maka pihak agen pelra menunjuk salah satu petugasnya untuk menempelkan barcodes pada tiap kategori muatan yang akan dikirim, setelah label tertempel maka pihak TKBM (Tenaga Kerja Bongkar Muat) bisa langsung mengangkut muatannya ke atas kapal, saat TKBM mengangkut muatan pihak kapal mengutus seorang mandor untuk mencatat tiap muatannya yang masuk menggunakan alat bantu pembaca barcodes, setelah semua muatan selesai terangkut maka nahkoda atau kapten kapal mengecek kesesuai jumlah muatan lalu menghubungi pihak agen pelra untuk berlayar apabila semua muatannya sudah sesuai oleh konosemen muatan yang diangkut. Setelah semua muatan selesai dimuat maka kapal berlayar menuju kota tujuan, setelah kapal tiba dan bersandar maka mandor kapal kembali menghubungi pihak agen pelra kota tujuan untuk bisa bongkar muatan. Pihak agen menunjuk petugasnya untuk mengamati dan mencatat muatan yang dibongkar, setelah semua sesuai dengan konosemen maka petugas kembali ke kantor untuk memberitahukan admin bahwa barang sudah sesuai dan bisa update website, ketika sudah ada di dermaga pelabuhan tujuan pihak agen bisa menghubungi penerima barang untuk mengambil langsung atau bisa dikirim lagi menggunakan jasa kurir. Ketika barang sudah sampai pada penerima dan sudah sesuai maka kurir menghubungi pihak agen bahwa barang sudah berhasil terkirim.

Penempelan label muatan baru dengan stiker yang kuat akan gesekan, berbentuk segi empat lalu ditempelkan pada sisi yang mudah dilihat atau dibaca dan mempunyai latar belakang yang menyolok atau kontras dan tidak tertutup oleh tanda lain (Gambar 16). Apabila terdapat sisa tanda yang

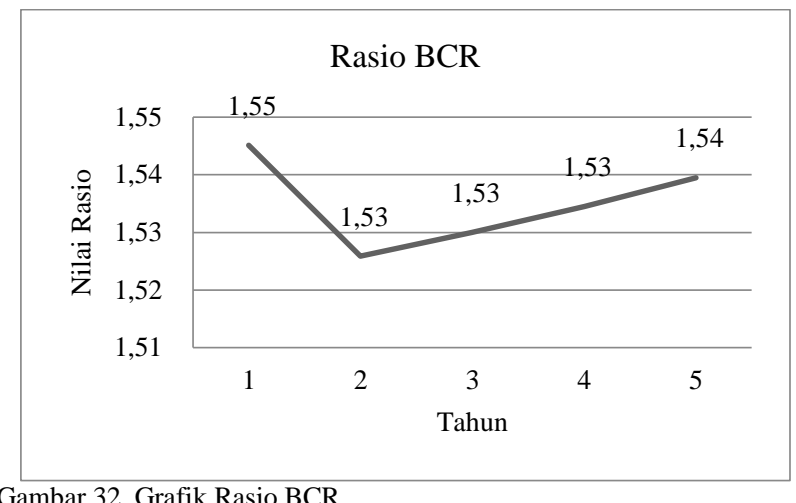

Gambar 32. Grafik Rasio BCR.

tidak perlu yang masih melekat pada kemasan, maka tanda lama tersebut harus dicabut dan diganti yang baru. Kaitannya dengan pemasangan tanda-tanda ini, pihak pengirim perlu mengadakan pemeriksaan ulang, apakah tanda-tanda pada kemasan telah lengkap dan memenuhi syarat, selain itu tiap kemasan tunggal juga diberikan tanda-tanda.

Dalam label yang baru ini (Gambar 17) harus terdapat penyampaian informasi yang bisa memudahkan untuk kegiatan operasional dan memiliki fungsi penunjuk terhadap petugas ketika menangani muatan. Detail yang harus ada antara lain, brand nama perusahaan pengirim atau logo perusahaan pengirim, nama dan alamat pengirim muatan, jenis muatan, berat dan volume muatan, alamat tujuan muatan beserta penerima muatan, barcodes untuk sistem komputerisasi muatan.

Dalam penempelan untuk kemasan kardus (Gambar 18), stiker ukuran panjang dikali lebar $(\mathrm{P} \times \mathrm{L})=15 \mathrm{~cm} \times 20 \mathrm{~cm}$. Penempelan label ditempelkan untuk tiap masing masing isi dalam box, apabila isi muatannya sama maka label barang disesuaikan untuk tiap tumpukkannya jadi tidak tiap box diberi label, apabila dalam satu kali pengiriman tiap isinya berbeda-beda maka harus menempelkan label masingmasing.

Dalam penempelan untuk kemasan karung (Gambar 20), stiker ukuran panjang dikali lebar $(\mathrm{P} \times \mathrm{L})=15 \mathrm{~cm} \times 20 \mathrm{~cm}$. Penempelan label ditempelkan untuk tiap masing masing isi dalam karung, apabila isi muatannya sama maka label barang disesuaikan untuk tiap tumpukkannya, biasanya di Pelra muatan karung paling tinggi tumpukannya adalah 6 tumpuk maka tumpukan paling atas yang akan diberi label muatan.

Dalam penempelan untuk kemasan palet kayu (Gambar 21), stiker ukuran panjang dikali lebar $(\mathrm{P} \times \mathrm{L})=10 \mathrm{~cm} \times 20$ $\mathrm{cm}$. Penempelan label ditempelkan untuk tiap masing masing isi palet kayu. Label ditempelkan pada siku palet kayu.

Dalam penempelan untuk kemasan ikatan (Gambar 22), stiker ukuran panjang dikali lebar $(\mathrm{P} \times \mathrm{L})=10 \mathrm{~cm} \times 20 \mathrm{~cm}$. Penempelan label ditempelkan untuk tiap masing masing isi ikatan. Label ditempelkan pada sambungan ikatan tali pengikat.

Dalam penempelan untuk kemasan triplek (Gambar 23), stiker ukuran panjang dikali lebar $(\mathrm{P} \times \mathrm{L})=10 \mathrm{~cm} \times 20 \mathrm{~cm}$. Penempelan label ditempelkan untuk tiap masing masing kemasan. Label ditempelkan pada sisi datar triplek.

Dalam penempelan untuk kemasan gulungan (Gambar 24), stiker ukuran panjang dikali lebar $(\mathrm{P} \times \mathrm{L})=10 \mathrm{~cm} \times 20 \mathrm{~cm}$. Penempelan label ditempelkan untuk tiap masing masing gulungan. Label ditempelkan pada sisi lengkung gulungan. Apabila gulungannya besar dan berbahan besi maka sebelum ditempel stiker ditambahkan kertas karton atau kardus lalu 
diikat dengan tali dan kemudian baru dipasangkan stiker label.

Dalam penempelan untuk kemasan plastic (Gambar 25), stiker ukuran panjang dikali lebarnya bervariasi tergantung muatannya apabila muatannya besar seperti tandon air maka $(\mathrm{P} \times \mathrm{L})=10 \mathrm{~cm} \times 20 \mathrm{~cm}$ apabila muatannya kecil seperti suku cadang motor maka $(\mathrm{P} \times \mathrm{L})=4 \mathrm{~cm}$ x $8 \mathrm{~cm}$. Penempelan label ditempelkan untuk tiap masing masing plastik. Label ditempelkan langsung pada kemasan plastik.

\section{J. Desain Antarmuka Web Penunjang}

Antarmuka aplikasi web digunakan untuk administrator sistem Pelra Expres. Gambar 26 adalah beberapa tampilan utama versi web yang telah dikembangkan:

Dalam halaman utama ada beberapa tampilan fitur untuk layanan yang dapat diakses oleh pengguna, fitur utama dalam halaman utama ini yaitu untuk melacak muatan lalu ada cek tarif untuk mengetahui berapa harga jasa yang ditawarkan, fitur titik layanan operasional untuk mengetahui rute mana saja yang dapat dikirimkan oleh agen pelra, serta fitur tentang kami yang berguna untuk menampilkan informasi telepon ataupun alamat pelra serta ada tambahan fitur live chat yang berfungsi sebagai wadah tanya jawab seputar pengiriman muatan melalui pelra. (Gambar 27)

Dalam halaman pelacakan kita tahu tiap titik barangnya berada dimana, jadi kita tahu ketika barang masih dalam dermaga, sedang berlayar hingga sampai tujuan. Dari awal ketika barang disetor ke agen sampai pusat sortir di dermaga lalu ketika akan berlayar sampai ketika tiba di kota tujuan lalu proses bongkar, lalu proses sortir sampai ketika muatan dibawa kurir kita tahu tiap detailnya

\section{K. Analisis Biaya}

Langkah yang dilakukan untuk mendapatkan nilai manfaat adalah dengan mengidentifikasi risiko-risiko yang ada pada setiap proses perpindahan muatan dan informasi. Pada setiap proses perpindahan muatan memiliki hazard dan frekuensi terjadinya hazard. Pada penelitian ini, penyusun memakai studi kasus satu periode pengiriman oleh KLM AL FATAH yang bekerjasama dengan PT. HARTINI. Berdasarkan wawancara dan pengamatan secara langsung, penyusun telah mengidentifikasi risiko yang terjadi pada satu periode pengiriman oleh KLM AL FATAH.

Perhitungan yang dilakukan untuk pengadaan perangkat keras dan perangkat lunak sebagai persyaratan untuk mengoperasikan Website Pelacakan Muatan Kapal Pelra ini menggunakan asumsi umur ekonomis website selama 5 tahun. (Gambar 28)

Biaya yang ditimbulkan hanya pada biaya operasional pengadaan internet Rp 4.800.000,- per tahun dan listrik Rp 72.000 .000 ,- per tahun dengan kenaikan 5\% pada tahun ke-2 dan $1 \%$ pada tahun berikutnya. (Gambar 29 dan 30)

\section{Analisis Waktu}

Dengan adanya sistem komunikasi yang baru pihak pelra dapat memangkas waktu sebanyak 91 menit. (Gambar 31)

\section{Rasio Biaya Manfaat}

Rasio biaya manfaat adalah perbandingan dari manfaat terhadap biaya tiap tahun, apabila memiliki nilai lebih dari 1, maka dapat disimpulkan solusi tersebut disarankan untuk direalisasikan, namun sebaliknya apabila nilainya kurang dari 1 maka solusi tersebut tidak disarankan untuk direalisasikan. Dengan asumsi kenaikan biaya operasional dan perawatan maka akan didapatkan grafik rasio biaya dan manfaat yang ditunjukkan pada Gambar 32.

Pada analisis biaya manfaat ini dapat disimpulkan bahwa memiliki nilai rasio yang lebih dari 1 sehingga gagasan ini disarankan untuk dilakukan investasi lebih lanjut. Rasio yang didapatkan dari perbandingan manfaat dan biaya pada tahun pertama adalah 1,55 dan mengalami penurunan pada tahun kedua dan kembali naik pada setiap tahunnya mulai dari tahun ketiga, keempat didaptkan nilai hingga pada tahun ke5 rasio manfaat dan biaya menjadi sebesar 1,54.

\section{KESIMPULAN}

Dari penelitian yang telah dilakukan maka dapat diperoleh kesimpulan sebagai berikut:

1) Sistem dapat melakukan pemantauan secara digital keberadaan barang pada pengirimanbarang mulai dari gudang sampai ke tempat tujuan.

2) Adanya sistem pelabelan muatan baru berupa barcodes dengan menggunakan stiker berukuran $15 \mathrm{~cm}$ x $20 \mathrm{~cm}$ untuk dapat mencatat muatan kapal dan dapat dipindai menggunakan barcodes scanner dengan adanya pencatatan ini maka dapat dikomputerisasi dan dapat melacak muatan.

3) Sistem dapat melakukan pemantauan terhadap keadaan barang seperti:

\section{a. Rute Pengiriman Barang}

b. Kondisi barang yang diterima oleh pelanggan.

c. Jumlah barang yang dikirim sesuai atau tidak dengan jumlah barang yang dipesan oleh pelanggan

4) Rasio yang didapatkan dari perbandingan manfaat dan biaya pada tahun pertama adalah 1,55 dan menurun pada tahun ke 2 lalu akan naik kembali setiap tahunnya hingga pada tahun ke-5 rasio manfaat dan biaya menjadi sebesar 1,54

\section{UCAPAN TERIMA KASIH}

Penulis mengucapkan terima kasih kepada pihak yang telah membantu proses penelitian ini. Kepada Ibu Endang selaku pemilik agen pelyaran PT. Setia Palenggu. , Bapak Saiful selaku mandor kapal rakyat Al-Fatah, Bapak Saleh selaku Dewan Perwakilan Cabang Pelra Kalimas serta instansi-instansi yang terkait atas semua bantuan dan dukungan yang diberikan terkait penyelesaian penelitian ini.

\section{DAFTAR PUSTAKA}

[1] Boehjle, Hofing, and Schroeder, "Value Chains in the Agriculture Industries," USA, 1999. 